\title{
Concentration of the Isotopes of Mercury by Free Evaporation in a 10-Cell Counter-Current Reflux Still ${ }^{1}$
}

\author{
By A. Keith Brewer ${ }^{2}$ and Samuel L. Madorsky
}

\begin{abstract}
Concentration of the isotopes of mercury was carried out in a counter-current molecular still consisting of 10 stages. Distillation temperatures varied from $55^{\circ}$ to $100^{\circ} \mathrm{C}$. A singlestage molecular still was operated, also with mercury, at temperatures varying from $108.1^{\circ}$ to $128^{\circ} \mathrm{C}$. The results agree with those obtained previously by other investigators operating with single-stage stills.
\end{abstract}

\section{Introduction}

Molecular distillation has been used by a number of investigators for concentrating the isotopes of mercury. The technic employed in each instance was essentially the same. Brönsted and Hevesy $[1]^{3}$ used a Dewar flask type still in which the mercury evaporating in the heated outer flask was frozen out on the chilled inner flask. Mulliken and Harkins [2] condensed the vapor on a cooled sloping glass roof, from which it ran in to a side reservoir. Harkins and Madorsky [3] used a large steel annular trough with a $\wedge$-shaped condensing roof.

Each investigator used a single still with one evaporating and one condensing surface. In order to obtain an appreciable concentration it was necessary to repeat the process many times. This required an elaborate system for collecting, recombining, and redistilling fractions.

Wollner, Matchett, and Levine [4] describe a multiple distillation apparatus which they used in purifying acetylated marihuana "red oil". No details are given as to temperature, rate of dis-

1 This paper covers experimental work carried out during the period June 17, 1940, to April 3, 1941. Two statements describing the method and most of the experimental work and dated June 24, 1940, and Nov. 25, 1940, respectively, were submitted to the Director of the National Bureau of Standards. Until recently it has been withheld from publication because of wartime security restrictions. It will be included in vol. 6, Div. III, of the Manhattan Project Technical Series.

2 Now at the U. S. Navy Department.

${ }^{3}$ Numbers in brackets indicate the literature references at the end of this paper. tillation, pressure inside the still, or as to whether a volatile fraction collected in the dry-ice-cooled trap. In view of the fact that organic liquids are subject to decomposition during high vacuum, high temperature, distillation, and that no provision was made to cool the condensing part of the still, except contact with air, it is doubtful whether they operated under conditions of nonequilibrium distillation.

The present paper describes an apparatus and technic in which a series of molecular stills have been arranged to operate under counter-current reflux. The new still is so designed that recombination of fractions is accomplished automatically by means of gravity feeds. The system acts as a reflux column in which each cell is a separate plate.

The mechanism of operation, under total reflux, is shown graphically in figure $2, A$. The vapor rising from the surface $a_{3}$ of the liquid in cell $A_{3}$ condenses on the sloping surface $b_{3}$ and runs down to drop into the adjacent cell $A_{4}$ higher up in the series. At the same time, the liquid level in cell $A_{4}$ is kept constant by means of a spillover, $S$, which allows the liquid to flow back into cell $A_{3}$. The flowback, in consequence, is exactly equal to the forward throughput. The over-all operation is such that the light fraction increases in concentration toward the upper end while the heavy fraction increases in concentration toward the lower end of the still. 


\section{Apparatus}

The evaporation apparatus is shown diagrammatically in figure 1 . The evaporating reservoirs were machined from an iron plate, $B$. Each reservoir was $2 \mathrm{~cm}$ wide, $7.5 \mathrm{~cm}$ long, and $0.8 \mathrm{~cm}$ deep at the shallow side. Spillovers $S$, figure $2, B$, were cut at alternate ends for adjacent cells to provide thorough mixing of the liquid. The capacity of each cell was $9 \mathrm{ml}$, and that of the entire system was $90 \mathrm{ml}$. The reservoirs were heated by a Nichrome coil imbedded in an alundum plate that was bolted directly to the reservoir block.

The condensing roofs, $C$, figure 1 , were made of iron wedges screwed to a supporting plate, $D$. The angle of slope could be varied by changing the wedges. The roofs were cooled by circulating alcohol at $-18^{\circ} \mathrm{C}$ through an iron coil immersed in a pool of mercury, $E$, in contact with plate $D$. The temperature of the mercury was kept near $0^{\circ} \mathrm{C}$ by a thermoregulator that operated the alcohol-circulating pump.

Loss of mercury from the evaporators was prevented by glass plates provided with notches to allow proper evacuation of each cell.

A high vacuum was obtained by enclosing the entire still in a glass cylinder with machined metal plates bolted across the ends; rubber gaskets coated with stopcock grease made the system vacuum-tight. The operating pressure, as read by a McLeod gage, was below $10^{-5} \mathrm{~mm} \mathrm{Hg}$.

Considerable difficulty was experienced in obtaining roofs that did not allow most of the condensed mercury to drop back into the same cell. In the first apparatus the machined surface of the iron wedges was used directly as the condensing surface; the angle was 25 degrees. A large fraction of the mercury dropped back into the same cell instead of running down into the next pool. Changing the slope of the wedges to 40 degrees made only a slight improvement. The condensing surfaces were then polished and blued at $300^{\circ} \mathrm{C}$. The results were fairly satisfactory. A special study of condensing surfaces carried out with a single-cell apparatus showed that glass was by far the most effective material. Glass plates $1 \mathrm{~mm}$ thick were then cemented to the iron roofs. This change was effective in giving a complete forward transport of the condensing mercury. An angle of 33 degrees was satisfactory.

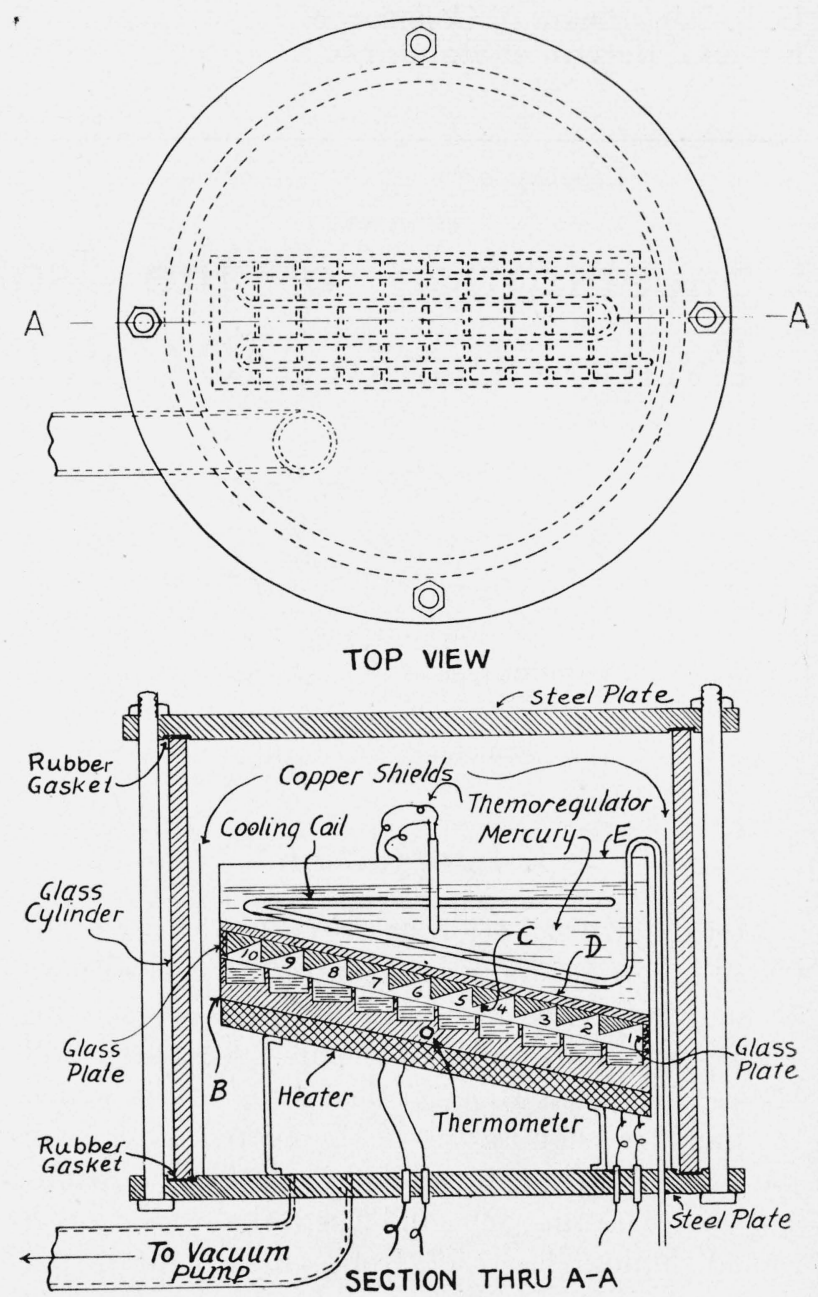

Figure 1.-Ten-cell cascade evaporation apparatus.

Purification and density determination of the mercury

The mercury was first purified by aeration for 24 hours in 10-percent nitric acid. It was then distilled three times, rejecting 10 -percent fractions at the beginning and end of each distillation.

The change in the isotope ratio was determined by the density method described by Mulliken and Harkins [2] and Harkins and Madorsky [3]. Several modifications were introduced to increase the accuracy of the measurements. The picnometer had a capacity of about $3 \mathrm{ml}$ and held about $40 \mathrm{~g}$ of $\mathrm{Hg}$. It was filled with the $\mathrm{Hg}$ sample at about $10^{\circ} \mathrm{C}$, then placed in a thermostat at $31.7^{\circ}$ $\pm 0.003^{\circ} \mathrm{C}$. The overflow of $\mathrm{Hg}$ was brushed off with the sharp edge of a piece of paper exactly at the time when the reading on a thermometer was 


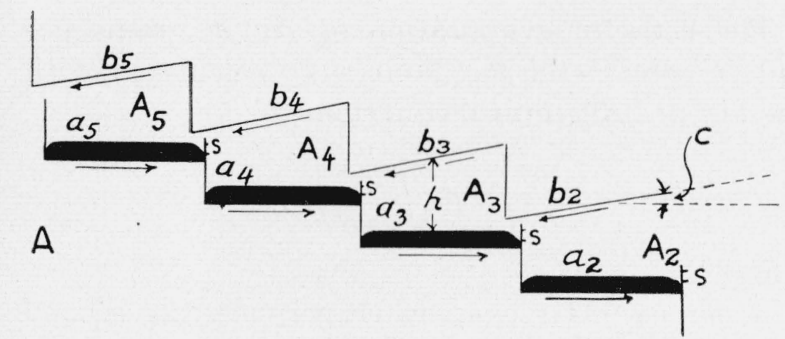

$B$
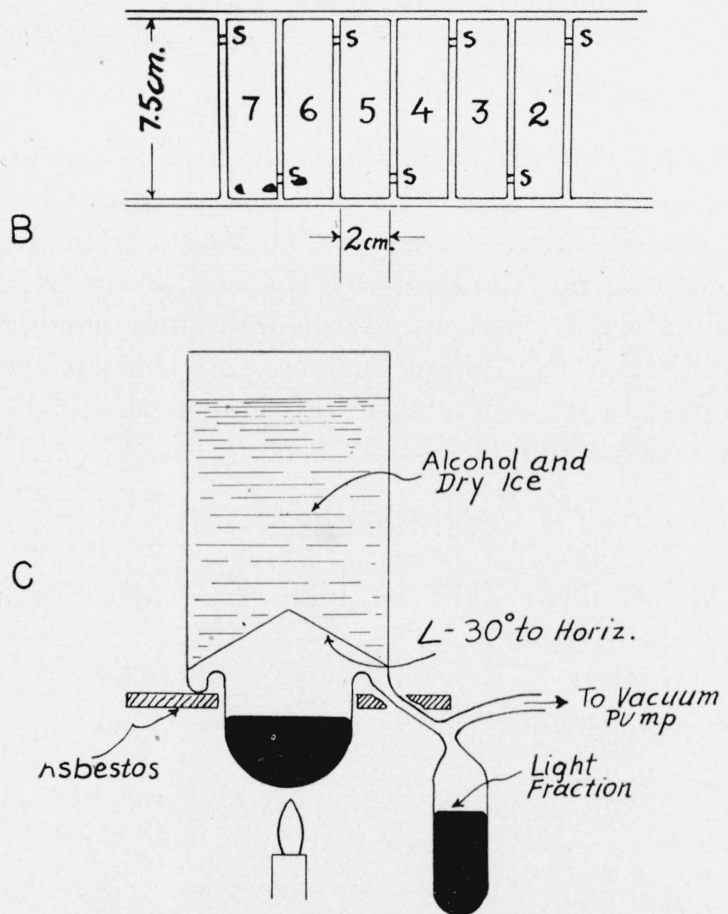

Figure 2.-Diagramatic view of cascade distillation and apparatus for single-stage operation.

$A$, diagram showing mechanism of cascade distillation; $B$, section through cells showing spillovers; $C$, Mulliken-type single-stage molecular still.

at a given point on the downward temperature variation of the bath. At first a razor blade was used to wipe off the mercury overflow, but it was found that the picnometer lost weight owing to scraping of the glass.

Weighings were made on a new chainomatic balance, using a counterpois picnometer having the dimensions as close to the original as possible. Magnifying glasses were used to read the zero on the pointer scale and the divisions on the chain dial. An accuracy of about 2 parts per million was obtained. As the total weight of the $\mathrm{Hg}$ was $40 \mathrm{~g}, 2 \mathrm{ppm}$ involved an accuracy of $0.08 \mathrm{mg}$.

In order to check the density measurements against isotope abundance ratios, samples of mercury of known density labeled No. 1 ordinary, No. 2 ordinary, and $A, B, C$, and $D$ were sent to A. O. C. Nier, at the University of Minnesota, for mass spectrometric analysis. The ratios for ${ }^{198} \mathrm{Hg}$ to ${ }^{204} \mathrm{Hg}$ were measured. These ratios with comparative density measurements are given in table.1.

TABLE 1.-Comparison between mass spectrograph analysis and density determinations of mercury

\begin{tabular}{|c|c|c|}
\hline Sample & $\begin{array}{l}\text { Change of } \\
\text { density of } \\
\text { mercury }\end{array}$ & $\begin{array}{c}\text { Ratio } \\
{ }^{199} \mathrm{Hg} /{ }^{204} \mathrm{Hg}\end{array}$ \\
\hline & $p p m$ & \\
\hline University of Minnesota, ordinary & - n-n & 1.456 \\
\hline No. 1, ordinary & -........ & 1.459 \\
\hline No. 2 , ordinary & (n) & 1. 457 \\
\hline$A$ & +10.9 & 1. 450 \\
\hline$B \ldots \ldots$ & -11.2 & 1.466 \\
\hline$C_{\ldots} \ldots \ldots \ldots \ldots$ & +30.6 & 1. 438 \\
\hline$D_{1}$ & -15.2 & 1.470 \\
\hline$E$ & +14.2 & 1.452 \\
\hline
\end{tabular}

\section{Temperature Measurements}

The temperature of the mercury in the cells was first determined by a thermometer and thermocouple inserted in plate $B$ (fig. 1). It was evident, however, that the power input was much too small to account for the evaporation of $\mathrm{Hg}$ at a rate corresponding to the plate temperature. $\mathrm{A} \mathrm{Pt}-\mathrm{Pt}-\mathrm{Rh}$ thermocouple inserted in the mercury gave incorrect readings because of stray contact potentials. In consequence, it was found necessary to estimate the temperature of the evaporating $\mathrm{Hg}$ surface from the power input into the heater, after correcting for radiation and conduction losses.

\section{Operational Procedure}

After the cell had been filled with mercury, the system was closed and evacuated to a sticking vacuum. In all the runs the operation was continuous. The mercury cooling bath was maintained at about $0^{\circ} \mathrm{C}$.

Runs II, III, and IV were made with the 40 degree polished and blued roofs; the average distance from the evaporating surface was $19 \mathrm{~mm}$. The duration was 2, 5, and 3 days, respectively. Run $\mathrm{V}+\mathrm{VI}$ was carried out for the first 6 days with blued iron roofs; the experiment was then stopped, and the glass-covered roofs were installed. The run was then continued for another 6 days. The slope angle was 33 degrees from the horizontal, 
and the average distance from the evaporating surface was $15 \mathrm{~mm}$. Runs VII, VIII, and IX were made with the same glass-covered roofs and lasted 3, 5, and 2 days, respectively. In run VII the mercury in the two lowest cells became mixed in sample taking. The conditions in run $\mathrm{X}$ were the same as in run IX, except that the temperature was higher. Soon after this run was started the glass plate fell off the roof in cell 5, and most of the condensate in this cell dropped back without reaching cell 6 . In consequence, the lower four cells and the upper six cells in run $\mathrm{X}$ operated as separate systems.

\section{Throughput}

The throughput in the present still is determined by the quantity of mercury carried forward from cell to cell. As the stills were operated under total reflux, this is necessarily the same as the quantity of mercury spilling back. The forward movement of mercury is determined by three factors: (1) the rate of escape from the liquid surface, (2) the fraction condensed on the roofs, and (3) the fraction of condensate dropping back into the same cell.
The rates of evaporation of $\mathrm{Hg}$ in grams per square centimeter per hour were calculated with the aid of Langmuir's equation [5]

$$
m=P \sqrt{\frac{M}{2 \pi R T}},
$$

where

$m=\left(\mathrm{g}\right.$ of $\mathrm{Hg}$ evaporated per $\left.\mathrm{cm}^{2}\right)$ per second $P=$ pressure in dynes per $\mathrm{cm}^{2}$

$M=$ molecular weight of $\mathrm{Hg}$

$R=$ gas constant $=8.3 \times 10^{7}$ ergs per $1 \mathrm{deg} \mathrm{C}$ $T=$ absolute temperature.

The fraction of the mercury condensing on the roofs cannot be told with certainity. Assuming that the direction of escape of molecules from the mercury surface is given by the cosine law, approximately 75 percent of the molecules leaving should strike the sloping surface. As this surface is cooled to $0^{\circ} \mathrm{C}$ condensation thereon should be very nearly complete.

\section{Results}

The pertinent data for nine consecutive runs are given in table 2 .

TABLE 2.-Concentration of isotopes of mercury in the 10-cell apparatus

\begin{tabular}{|c|c|c|c|c|c|c|c|c|c|}
\hline Experiment No. & Time & $\begin{array}{c}\text { Tempera- } \\
\text { ture }\end{array}$ & $\begin{array}{l}\text { Vapor } \\
\text { pressure }\end{array}$ & $\begin{array}{l}\text { Rate of } \\
\text { evapora- } \\
\text { tion }\end{array}$ & Kind of roof & $\begin{array}{l}\text { Angle to } \\
\text { horizon }\end{array}$ & A verage, $h$ & $\begin{array}{l}\text { Number } \\
\text { of plates }\end{array}$ & $\begin{array}{c}\text { Total } \\
\text { change } \\
\text { in density }\end{array}$ \\
\hline II.. & $\begin{array}{r}\text { Days } \\
2\end{array}$ & ${ }^{\circ} \mathrm{C}$ & $\begin{array}{r}m m \mathrm{Hg} \\
0.017\end{array}$ & $\begin{array}{c}\left(g / \mathrm{cm}^{2}\right) / h r \\
\text { 2. } 95\end{array}$ & Iron & $\begin{array}{r}\text { Degrees } \\
40\end{array}$ & $\begin{array}{l}m m \\
\quad 19\end{array}$ & 9 & $\begin{array}{c}p p m \\
21.8\end{array}$ \\
\hline III & 5 & 70 & .048 & 7.75 & _....do do ..... & 40 & 19 & 9 & 45.9 \\
\hline IV ..... & 3 & 70 & .048 & 7.75 & _._. do & 40 & 19 & 9 & 29.6 \\
\hline $\mathrm{V}+\mathrm{VI}$ & 12 & 75 & .067 & 10. 26 & Iron and glass.... & 40,33 & 19,15 & 9 & 129.4 \\
\hline VII ..... & 3 & 75 & .067 & 10. 26 & Glass & 33 & 15 & 8 & 78.2 \\
\hline VIII_.. & 5 & 75 & .067 & 10. 26 & _ do & 33 & 15 & 9 & 161.6 \\
\hline IX & 2 & 75 & .067 & 10.26 & ._. do & 33 & 15 & 9 & 85.7 \\
\hline $\mathrm{X}$ & 2 & 100 & .273 & 42.03 & _._...do do & 33 & 15 & 5 & 79.8 \\
\hline
\end{tabular}

The change in density of the mercury in the individual cells for each run is given in figures 3 and 4 .

Runs II and IV are of the type to be expected in a reflux column in the initial stages of operation. The concentration predominates at the ends with very little effect in the central portion. Run III is characterized by a nonuniformity of transport between cells. All three runs were made with iron roofs in which a large fraction of the condensed mercury fell back into the cells from which it evaporated. As some of the roofs behaved more efficiently than others, the erratic shape of line III is to be expected.

Run V+VI shows a uniform rate of change in density from cells 5 to 10 . This is indicative of equilibrium having been established in that portion of the column. In the lower cells from 4 down, the difference in density decreases slightly toward the bottom. This dropping off in the efficiency in the lower cells was expected as droplets of mercury were regularly observed to form in the upper part of the column and run along the walls to fall principally into cell 1 . The constant 


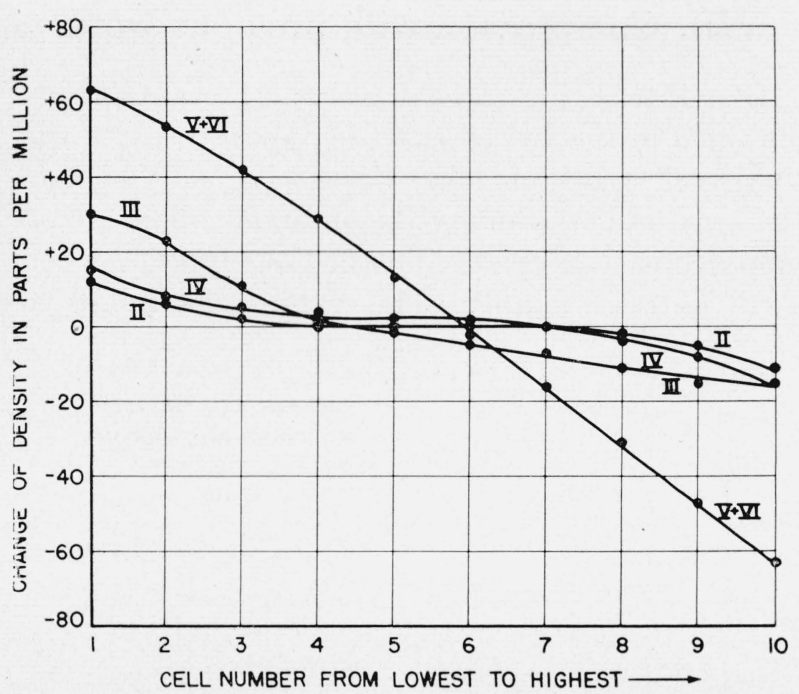

Figure 3.-Results obtained in runs $I I, I I I, I V$, and $V$ plus VI where polished steel roofs were used.

II, 2 days at $55^{\circ}$; III, 5 days at $70^{\circ}, \mathrm{IV}, 3$ days at $70^{\circ}$; V plus VI, 12 days at $75^{\circ}$.

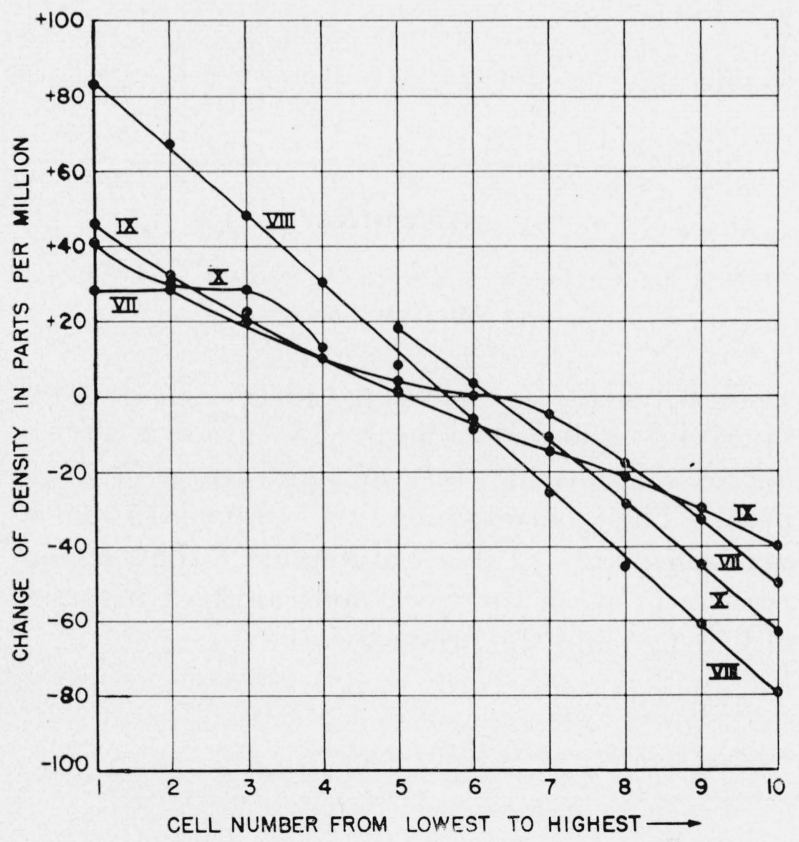

Figure 4.--Results obtained in runs VII, VIII, IX, and X, where glass-covered roofs were used.

VII, 3 days at $75^{\circ}$; VIII, 5 days at $75^{\circ}$; IX, 2 days at $75^{\circ} ; \mathrm{X}, 2$ days at $100^{\circ}$.

addition of light mercury from the top cells to the bottom cell gives rise to the observed decrease in rate.

It should be pointed out that a small difference in density between the two lowest cells might indicate impurity in the mercury. As any impurity that might be present would of necessity be lighter than mercury and at the same time have a lower vapor pressure, it would soon concentrate in the lowest cell and lower the density of the $\mathrm{Hq}$ in that cell. The possibility of impurities in the mercury, however, has been carefully considered and shown to be absent. The straight line obtained in run VIII is also definite proof for the absence of impurities.

Runs VII, VIII, IX, and X were made with glass plates on the condensing roofs. Visual observation showed most of the mercury droplets falling into the next cell higher up. The quantity of mercury running down the walls and dropping into the lower cells was small.

Runs VII and IX are of the character to be expected when equilibrium has not been attained between the various cells. The contour of the curve for run VII indicates that the throughput is not uniform between the various cells as equilibrium is much nearer attained in the top three cells than in the remainder.

Run VIII is characteristic of a counter-current system operating under total reflux when equilibrium has been established between all cells.

The results obtained at $100^{\circ} \mathrm{C}$ are illustrated in run X. As the glass plate on cell 5 fell off during operation, the data are not complete for the entire system. They do show, however, that cells from 6 to 10 were in equilibrium. The separation per plate, as shown by figure 4 , is $17.3 \mathrm{ppm}$.

Figure 5 shows that the separation values are in general agreement with those to be expected from single-stage stills. As the exact temperature of the evaporating surface was not known in any instance, a more precise agreement cannot be expected.

\section{Free Evaporation of Mercury at High Temperatures}

The 10-cell cascade system was not designed for a study of free evaporation at temperatures above about $100^{\circ} \mathrm{C}$. As such knowledge is essential in working out more efficient still designs, tests at temperatures above $100^{\circ} \mathrm{C}$ were made in a singlestage glass molecular still similar to the one used by Mulliken and Harkins [2]. The still is illustrated in figure 2, C.

The capacity of the evaporator was $200 \mathrm{~g}$ of $\mathrm{Hg}$ (fig. 2, C), the evaporating surface was 10 $\mathrm{cm}^{2}$, and the condensing surface had an angle of 
30 degrees. The roof was cooled by an alcoholdry-ice mixture, and the evaporator was heated with an oxy-gas blast-lamp. The temperature of the mercury evaporating surface was calculated from the quantity of mercury evaporated per unit time, using Langmuir's equation.

Four runs at different temperatures were made. In the final run the full force of the oxy-gas flame was used. The cut, $C$, in each run was approximately 2. The pertinent data for these experiments are given in table 3.

TABLE 3.-Concentration of isotopes of mercury in a singlestage apparatus

\begin{tabular}{|c|c|c|c|c|c|c|}
\hline $\begin{array}{c}\text { Experiment } \\
\text { No. }\end{array}$ & Time & $\begin{array}{l}\text { Temper- } \\
\text { ature }\end{array}$ & $\begin{array}{l}\text { Vapor } \\
\text { pres- } \\
\text { sure }\end{array}$ & $\begin{array}{l}\text { Rate of } \\
\text { evapo- } \\
\text { ration }\end{array}$ & $\begin{array}{l}\text { Change } \\
\text { in density } \\
\text { of light } \\
\text { fraction } \\
\text { per cut }\end{array}$ & $\begin{array}{l}\text { Change } \\
\text { in den- } \\
\text { sity per } \\
\text { plate }\end{array}$ \\
\hline $\begin{array}{l}\text { XI } \\
\text { XII } \\
\text { XIII } \\
\text { XIV }\end{array}$ & $\begin{array}{c}\min \\
11 \\
8 \\
6 \\
4\end{array}$ & $\begin{array}{c}{ }^{\circ} \mathrm{C} \\
108.1 \\
114.8 \\
120.7 \\
128.0\end{array}$ & $\begin{array}{c}m m \mathrm{Hg} \\
0.417 \\
.570 \\
.770 \\
1.075\end{array}$ & $\begin{array}{c}\left(\mathrm{g} / \mathrm{cm}^{2}\right) / \\
\mathrm{hr} \\
62.8 \\
87.3 \\
113.7 \\
161.0\end{array}$ & $\begin{array}{r}p p m \\
10.50 \\
10.40 \\
8.05 \\
4.80\end{array}$ & $\begin{array}{r}\text { ppm } \\
15.15 \\
15.01 \\
11.62 \\
6.93\end{array}$ \\
\hline
\end{tabular}

The change in density, $\Delta D$, of the light fractions was obtained by dividing the total difference in density between the light and heavy fractions by 2 . The change of density per plate, $\Delta D^{\prime}$, was computed from the equation given by Mulliken and Harkins [2]:

$$
\Delta D=\Delta D^{\prime} \frac{\ln C}{C-1},
$$

where $\Delta D$ and $\Delta D^{\prime}$ are expressed in parts per million. Then

$$
\Delta D^{\prime}=\Delta D / 0.69315 .
$$

\section{Comparison with previous work}

It is interesting to compare the present results obtained in the 10-cell cascade apparatus with the single-cell work at the University of Chicago. Harkins and Madorsky [3] obtained about 16.50 ppm decrease in density for the light fraction when a cut of 2 was made. This value corresponds to

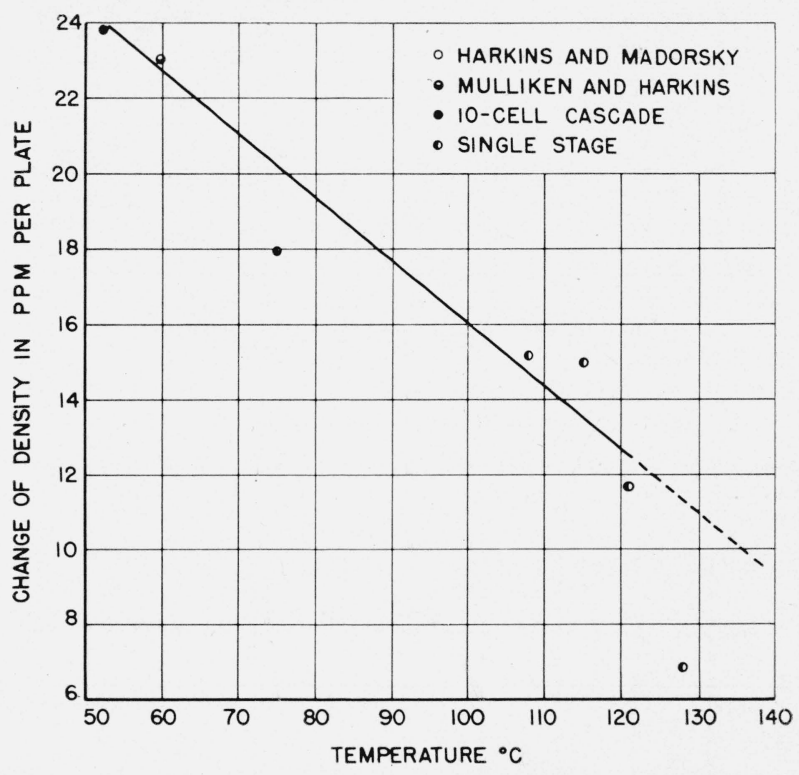

FIGURE 5.-Comparison between the present work and that by other investigators

$16.50 / 0.69315=23.80 \mathrm{ppm}$ per plate. In the work of Mulliken and Harkins [2], a cut of 2 gave a decrease in density for the light fractions of 16 ppm. This corresponds to $16 / 0.69315=23.08$ ppm per plate. Table 4 and figure 5 show a comparison between the work done at the University of Chicago and the present work.

\begin{tabular}{|c|c|c|c|c|c|c|c|}
\hline Reference & $\begin{array}{l}\text { Number } \\
\text { of cells } \\
\text { in still }\end{array}$ & $\begin{array}{l}\text { Rate of } \\
\text { evapora- } \\
\text { tion }\end{array}$ & Calculated & $\begin{array}{l}\text { Vapor } \\
\text { pressure }\end{array}$ & Cut & $\begin{array}{l}\text { Change in } \\
\text { density of } \\
\text { light frac- } \\
\text { tion per cut }\end{array}$ & $\begin{array}{l}\text { Change } \\
\text { in density } \\
\text { per plate }\end{array}$ \\
\hline Harkins and Madorsky & 1 & $\begin{array}{c}\left(\mathrm{g} / \mathrm{cm}^{2}\right) / \mathrm{hr} \\
2.37\end{array}$ & $\begin{array}{l}T^{\circ} C \\
\quad 52,0\end{array}$ & $m m \mathrm{H}_{0.015}$ & 2 & $\begin{array}{l}p p m \\
16.50\end{array}$ & $\begin{array}{l}p p m \\
23.08\end{array}$ \\
\hline Mulliken and Harkins & 1 & 4.00 & 59.5 & .025 & 2 & 16.00 & 23.80 \\
\hline Present work, experiment VIII & 10 & 10.27 & 75.0 & .067 & .. & .......... & 17.95 \\
\hline Present work, experiment XI & 1 & 62.8 & 108.1 & .417 & 2 & 10.50 & 15.15 \\
\hline Present work, experiment XII . . . . . . & 1 & 87.3 & 114.8 & .570 & 2 & 10.40 & 15.01 \\
\hline Present work, experiment XIII .......... & 1 & 113.7 & 120.7 & .770 & 2 & 8.05 & 11. 62 \\
\hline Present work, experiment XIV & 1 & 161.0 & 128.0 & 1.075 & 2 & 4.08 & 6.93 \\
\hline
\end{tabular}

TABLE 4.-Concentration of isotopes of mercury; comparison with previous work 


\section{Conclusions}

The results presented in this paper demonstrate that a series of individual molecular stills can be arranged in counter-current reflux in such a manner that the throughput between cells is entirely controlled by gravity feed. The advantages of the present reflux still over the single-stage still are many: (1) The quantity of material required to give a desired separation is materially smaller, (2) the holdup is vastly lower, (3) the time required for a given separation is very much shorter, (4) the labor involved is less; this is illustrated by the fact that to realize the separation obtained in one operation in the present 10-compartment still, 55 individual recombinations and distillations would have to be made with single-stage stills, (5) the operation can be made continuous; the material to be concentrated can be fed into the system at one end or at the midpoint, if both light and heavy fractions are of interest, and the concen- trate can be withdrawn continuously at the ends, and (6) The entire separation can be run without exposing the material to the atmosphere. This is particularly desirable for liquids that are susceptible to decomposition upon exposure to air.

The authors express their appreciation to J. W. Westhaver for his many basic contributions to this research.

\section{References}

[1] Brönsted and Hevesy, Phil. Mag. [6] 43, 31 (1922).

[2] Robert S. Mulliken and W. D. Harkins, J. Am. Chem. Soc. 44, 37 to 65 (1922).

[3] W. D. Harkins and S. L. Madorsky, J. Am. Chem. Soc. 45, 591 (1923).

[4] H. J. Wollner, John R. Matchett, and Joseph Levine, Ind. Eng. Chem., Anal. Ed. 16, 529 (1944).

[5] I. Langmuir, Phys. Rev. 2, 329 (1913).

Washington, November 19, 1946. 